\title{
COMPARATIVE AND COMPETITIVE ADVANTAGES ANALYSIS OF CASSAVA, CASE IN SIMALUNGUN DISTRICT, NORTH SUMATERA PROVINCE, INDONESIA
}

\author{
Junnia Pramesthia Putri ${ }^{1{ }^{* *},}$, Suhartini ${ }^{2}$, Nuhfil Hanani $\mathbf{A R}^{3}$ \\ ${ }^{1}$ Graduate Program Faculty of Agricultural Economics, University of Brawijaya, Indonesia \\ ${ }^{2}$ Department of Socioeconomics Faculty of Agricultural Economics, University of Brawijaya, Indonesia \\ Email : jpramesthia@gmail.com
}

\begin{abstract}
This study aims to analyze the competitive advantage and comparative advantage of cassava in Simalungun Regency, North Sumatera Province, which will be focused on increasing the production more better and more diversified through the approach of cassava farming activities. This context, based on the demand side of cassava commodity that is feasible to be developed by increasing its production in order to influence the level of income that will be received by farmers. This paper is proposed to: (a) analysis of farming both financially and economically, (b) comparative and competitive analysis, (c) to formulate the interim policy assumption of both advantages. Result of Matrix Policy Analysis Method (PAM), indicating that both of these commodities has a comparative and competitive advantage, shown by the ratio of DRC and PCR less than 1. Calculation shows DRC for cassava equal to 0.259 . PCR of cassava farming is 0.66 . This value means that cassava farming in Simalungun district can be said to have superiority comparative and competitive advantage. In other words, cassava farming at more research sites more better to be produced domestically rather than imported.
\end{abstract}

Keywords: Comparative dan Competitive Advantage, Policy Analysis Matrix, Cassava Commodities

http://dx.doi.org/10.21776/ub.agrise.2019.019.1.2

Received 31 Juli 2018

Accepted 15 January 2019

Available online 2 March 2019

\section{INTRODUCTION}

Cassava is one of the bulbs plants that are regarded planting as instead of rice and potatoes. Keep in mind that cassava has a complex carbohydrate than rice, as well as a source of kabohydrate dan is also minimal to the content of glucos than rice. Cassava also has some vitamins such as B and $\mathrm{K}$ vitamins that help in bone formation and keep brain damage, and good for digestion because of high fiber content. Cassava can suppose to be an alternative energy source (bioethanol).

The benefit of cassavas need to develop both in terms of cultivation and processing, considering this plant that is not difficult to be cultivated and very suitable to be grown in countries that have a tropical climate, one of which is our country
Indonesia. The production of cassava in Indonesia in 2016 was recorded at 2,074,467.8 tons/hectare from all provinces in Indonesia.

Indonesia has 8 provinces that are central to cassava cultivation, where the eight provinces contribute to the area of land that has been used for cassava cultivation. Lampung Province is the region that has the largest cassava area of 295,548 thousand hectare with a national cassava harvest area share of $29.07 \%$, then the East Java province has contributed to the harvest area of $15.53 \%$ with a total land area of 157,899 thousand Ha. The third position is the province of Central Java with a land area of 155,660 thousand $\mathrm{Ha}$ with a share of $15.31 \%$. The three provinces above are considered to be the largest central share in the national cassava harvest area. 
For the other 5 provinces, it was able to contribute $8.95 \%$ to the province of West Java, followed by the province of East Nusa Tenggara with a share of $7.15 \%$, DI Yogyakarta succeeded in contributing $5.62 \%$, in seventh position there was North Sumatra with a share of harvest area of 4 , $18 \%$ and the last is South Sulawesi with a share of $2.52 \%$ (figure 1 ).

However, the largest share in the national cassava harvest area does not guarantee that every province will have a high harvest area and will also produce high productivity. As summarized by the Agricultural Research and Data Center, Lampung province, which is considered to have the largest harvested share, does not yet have the best productivity. Whereas for North Sumatra province which can only contribute $4 \%$ in the national cassava harvest area, it turns out to have better productivity than Lampung, which is in the first position, can be seen in Figure 1.

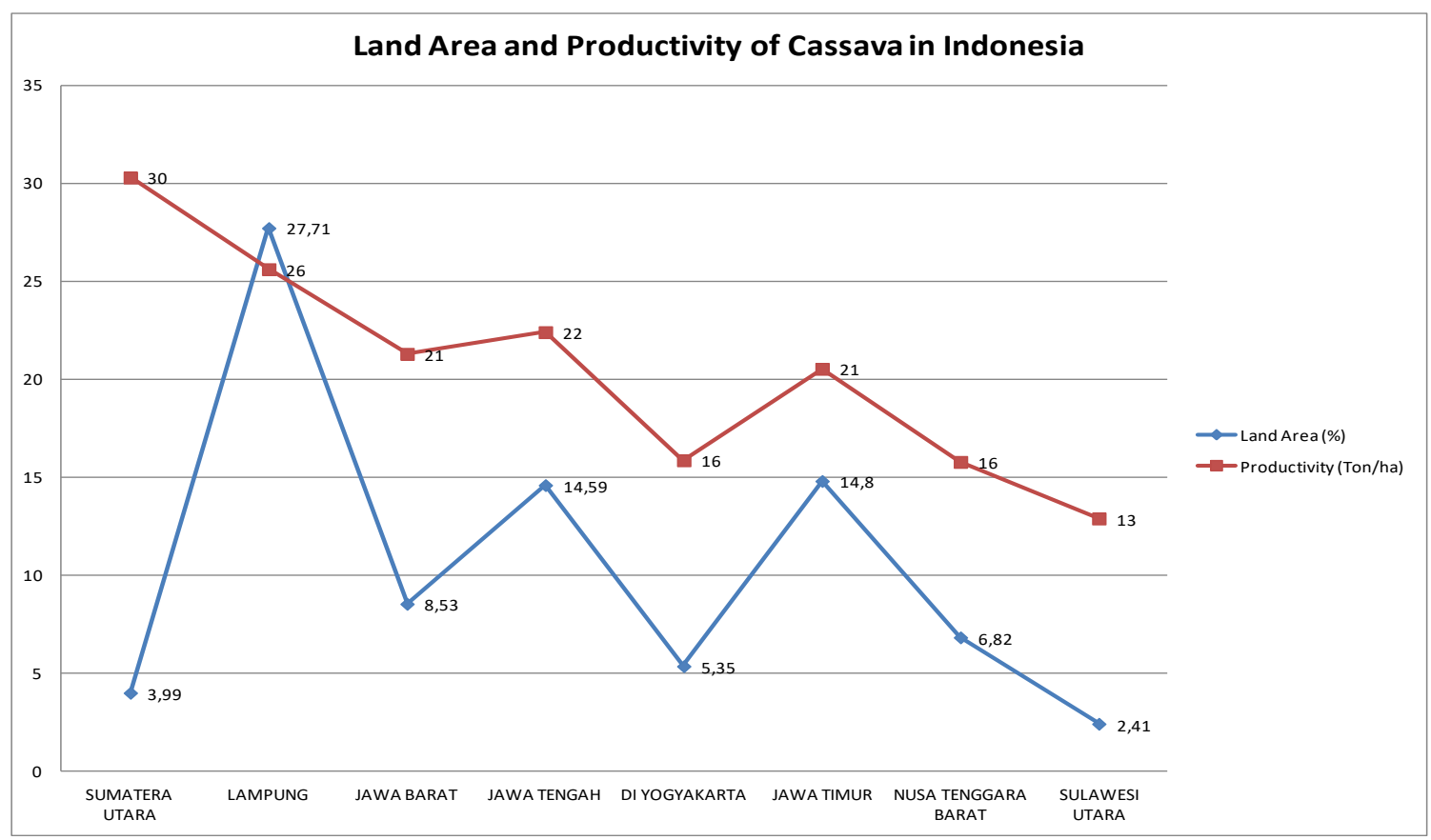

Figure 1. Graph of Land Area and Central Productivity of Cassava in Indonesia

One of the influencing aspects for productivity of cassava is the type of soil and climate that support the development of cassava in the location other than the means of production. With the potential of this province of North Sumatra, should be a special attention for cassava farming in Indonesia is still growing and we can enjoy all the time. One of the largest cassava producing regions in North Sumatera is Simalungun regency, where the area is one of the largest cassava growing area in North Sumatera Province which is about 8,625.2 hectare nd can be contribute to production in North Sumatera $60 \%$. The results of the initial research in Simalungun Regency also succeeded in producing cassava for 39 tons/hectare during one planting season.

With the potential that has been owned by Simalungun Regency in terms of soil type, climate and other supporting production facilities, it is necessary to give special attention to the production of cassava in this area is still running and able to compete in domestic and foreign needs. For that researchers here will be more focus on how competitive advantage of cassava in Simalungun Regency that has been farmers for this. In addition to knowing whether the business on the road is feasible when viewed in terms of superiority, and provide information to farmers how the business situation that they run at this time.

One of the influencing aspects for productivity of cassava is the type of soil and climate that support the development of cassava in the location other than the means of production. With the potential of this province of North Sumatra, should be a special attention for cassava farming in Indonesia is still growing and we can enjoy all the time. One of the largest cassava producing regions in North Sumatera is Simalungun regency, where 
the area is one of the largest cassava growing area in North Sumatera Province which is about 8,625.2 hectare and can be contribute to production in North Sumatera $60 \%$. The results of the initial research in Simalungun Regency also succeeded in producing cassava for 39 tons/hectare during one planting season.

With the potential that has been owned by Simalungun Regency in terms of soil type, climate and other supporting production facilities, it is necessary to give special attention to the production of cassava in this area is still running and able to compete in domestic and foreign needs. For that researchers here will be more focus on how competitive and competitive advantage of cassava commodity in Simalungun Regency that has been farmers for this. In addition to knowing whether the business on the road is feasible when viewed in terms of superiority, and provide information to farmers how the business situation that they run at this time.

\section{RESEARCH METHODS}

Site selection is purposively determined by using purposive method, where the researcher chooses the location of research based on the characteristics and reasons considered to be related the problem studied. The study was conducted in Simalungun Regency, North Sumatera Province with the consideration that the regency is one of the central of cassava farming in North Sumatera and as a supplier of raw material in the manufacture of processed food or tapioca flour. This research was conducted from March 2017 to December 2017.

In this study the population is does not known in the number, for that researchers use the theory of Wibisono. Determination of the number of respondents (samples) using Wibisono's theory, which is explained in the theory that if used to estimate $\mu$ to be obtained $(1-\alpha) \%$ it is believed that the error will not exceed the value, the formula is:

$$
\begin{aligned}
& n=\left(\frac{Z_{\alpha}^{\alpha} \cdot \sigma}{e}\right)^{2} \square n=\left(\frac{(1,96) \cdot(0,25)}{0,05}\right)^{2} \\
& n=\left(\frac{3.8416 .00625}{0,0025}\right)=96,04
\end{aligned}
$$

The result of the Wibisono (2005) formula is the minimum number of samples taken which will represent the large population in the study area of 96 respondents. For that researchers here took as many as 98 respondents.

Policy Analysis Matrix (PAM) was first proposed by Monke and Pearson (1989), PAM is an analysis system that is used to measure government policy by including several policies that will affect revenue and agricultural production costs. In this will investigate the comparative and competitive advantages level and the impact of changes in assumptions on policy. Before analyzing using PAM, the first will be analysis of farming that will know cost of production cassava farming that have been issued by farmer and to know revenue and income that will be accepted by farmer. For the research flow can be seen in Figure 2.

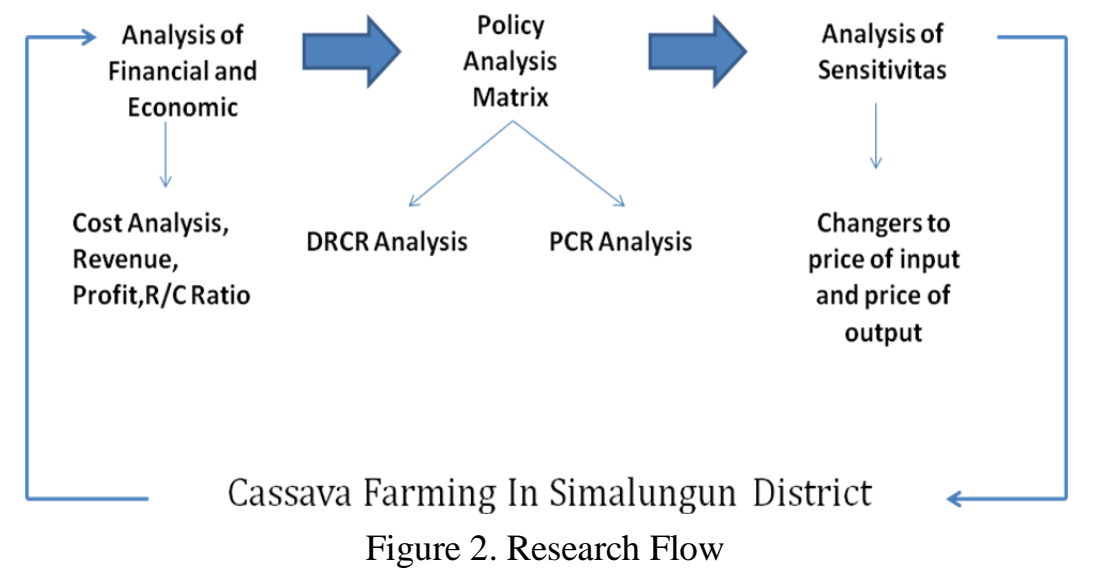

RESULT DATA ANALYSIS

\section{Farming Analysis}

Agricultural Socio-Economics Journal
Farming analysis is used to find out the total cost that farmers have spent during the cultivation process of cassava plant in Simalungun Regency. The total cost is fixed costs and variable costs, 
fixed cost is the cost incurred by the farmer where the cost is not affected by the volume of production (rent of land and the depreciation of agricultural equipment), and variable cost is the production cost of the small cost is influenced by the production volume (seed, fertilizer, pesticide and labor). After knowing the total cost incurred by farmers, we will analyze the farmer's receipt obtained from the quantity of production multiplied by the selling price received by farmers. In the sense that the revenue is still gross income. to get a net income (profit) the proceeds less the total cost incurred. To get a profit researcher use this formula (Soekartawi, 1998) :

$$
\begin{aligned}
& \Pi=\mathrm{TR}-\mathrm{TC} \\
& \Pi=\mathrm{Py} . \mathrm{Y}-(\mathrm{FC}+\mathrm{VC}) \\
& \Pi=\text { Py. } \mathrm{Y}-\left(\mathrm{r} . \mathrm{x}+\mathrm{b}^{\circ}\right)
\end{aligned}
$$

That formula above explains farming analysis in terms of income. Where income is the difference between total revenue and total production costs incurred during cassava farming activities in the research location. $\Pi$ is a profit, TR $(\mathrm{Py}, \mathrm{y})$ is total revenue from price of output multiplied by product quatity, TC are total cost from fixed (FC) cost and varible (VC) cost obtained from the input price multiplied by the quantity of input needed.

\section{Input and Output Determination and Grouping of Domestic and Foreign Cost Components}

In this study, inputs used in cassava business activities consist of seeds, anorganic fertilizers, pesticides, labor, agricultural equipment, and land. While the output in this study is fresh cassava. Production costs in farming activities can come from domestic (available around the location of cassava farming) and foreign (available on the international market). Production costs will be assumed that all tradable input costs are valued at $100 \%$ of foreign cost components and all non tradable input costs are valued at $100 \%$ of the domestic cost component.To determine the goods entered in tradable input and non tradable input we must know the goods the composition comes from abroad or domestic. import export data can be seen in import export catalog from BPS, later than the value of export and import, if the export value is greater then we will use f.o.b and if the value of import is greater then the value used is c.i.f. It can

\begin{tabular}{|c|c|c|c|}
\hline No & Input of Production & Domestic Cost (\%) & Foreign Costs (\%) \\
\hline 1 & Land & 100 & 0 \\
\hline 2 & Seed & 100 & 0 \\
\hline 3 & Anorganic Fertiliser & 0 & 100 \\
\hline 4 & Pesticide & 100 & 0 \\
\hline 5 & Labor & 100 & 0 \\
\hline 6 & Hoes & 0 & 100 \\
\hline 7 & Handsprayer & 0 & 100 \\
\hline
\end{tabular}
be seen at the Tabel 1 .

Table 1. Composition for Input

Source: Central Data Statistics Republic Indonesia, 2017

\section{Shadow Price Determination}

The price of shadow or social price is a price that can be from a price that reflects the true conditions in the economy with perfect competitive conditions. Determination of shadow prices for tradable and non tradable inputs and outputs as well as rupiah exchange rate against the dollar, as follows:

a. Shadow price of input tradable

1) The Price of Inorganic Fertilizer Shadow.

At the activity of cassava farming at research location using inorganic fertilizer like Urea. Determination of the price of inorganic fertilizer shadow using CIF value because import value is higher than its export value.

Cost of Anorganik Fertilizer (CAF)

$\mathrm{CAF}=($ c.i.f $\times$ SER $)+$ Cost of Trading
Price of CIF for Urea fertilizer is US\$ $0.24 / \mathrm{kg}$, so the price of shadow for Urea fertilizer use CIF is Rp. 2,200/kg.

2). Price of Pesticide Shadow.

Determination of the price of pesticide shadow in this study in accordance with the actual price. According to Maharani et al. (2014), the types and types of trademarks of pesticides used by cassava growers in various research sites. In addition, pesticide trade has been submitted to the market and the unavailability of pesticide price data at the international level.

(3) Shadow Price of Agricultural Equipment Agricultural equipment used by cassava farmers in Simalungun Regency are hoes and handsprayer. The shadow price of the farm equipment is obtained based on the depreciation value. Depreciation value is obtained from the actual price divided by $(1+$ import duty $)$ 
divided by the economic age. Then the result of the calculation is divided by the number of planting season in a year. The result of the calculation will get the value of depreciation equipment in one growing season called the shadow price of agricultural equipment depreciation with an import duty of $7.5 \%$.

b.Shadow Price Input Domestic (Input Non Tradable)

1) Shadow Price of Seeds.

Cassava seedlings used are seeds obtained from their own stem crops so that the determination of the price of shadow from cassava seedlings is using actual prices that are located in the study. The price of seed shadow at the research location is $\mathrm{Rp} 75$ / stem.

2) Shadow Price of Labor.

Determination of the price of labor shadow in this study using the actual price applicable in the research location. This is because the needs of labor in farming activities can be met by local people using human labor and agricultural equipment rental (tracktor). The price of labor shadow at the research location uses the actual price average Rp $66,861 / \mathrm{HOK}$. For the tracktor uses aktual price avergae is Rp.456.267.hactare.

3) Shadow price of Land.

In this study, the price of land shadow used is the actual price of land rent that is valid for research location in one year. but land shadow prices are only used for 10 months due to the age of cassava ranging from 9 months to 10 months.

4) Shadow Price of Trading Cost

The price of the trade includes the costs incurred in handling and transporting the input production farming cassava. The cost of the business is an estimate of the calculation of the farmer from the farmer's level to the consumer or from the port to the research location. The shadow price of the marketplace uses the actual price/market price. The shadow price of trading cost at research location is $\mathrm{Rp} 320 / \mathrm{kg}$.

c. Price shadow of output

The output is in the form of crops from cassava farming. The price of output shadow using import border or CIF price is US \$ 0.0656 (BPS 2017). This is because the value of cassava imports is greater than the value of cassava export. And the price when viewed from rupiah is Rp. $1186 / \mathrm{kg}$

d. Price shadow exchange rate

The calculation of the shadow price of the exchange rate can be adjusted to the official exchange rate based on the Jakarta Interbank Spott Dollar Rate (JISDOR). JISDOR is the reference rate of the US dollar exchange rate against the rupiah made by Bank Indonesia. JISDOR is structured according to the exchange rate of foreign exchange transactions against rupiah between banks in the domestic market in order to provide a representative market price reference for USD and IDR spot market transactions domestically. The shadow exchange rate of the rupiah or SER (Shadow Exchange Rate) in this study uses the average exchange rate in March - December 2017 of Rp.13,204 per US\$. (Bank Indonesia, 2017).

\section{Economic Analysis}

This analysis to know the total cost incurred, the total revenue and profit obtained by farmers in cassava farming activities. The analysis is to determine the feasibility of a farming done by the cassava farmers economically. Calculation of costs incurred during cassava farming activities are as follows:

Total Cost $=$ Tradable Input + Non Tradable Input

Furthermore, after the calculation of the total cost, the calculation of revenue from cassava farming activities. Revenue is the result of multiplication between the amount of production produced and the selling price per unit of production.

\section{Analysis of Domestic Resource Cost (DRC)}

DRC (Domestic Resource Cost) can measure the level of efficiency or comparative advantage of a cassava business (Pearson, et al, 2005). In DRC measurement use shadow price. The formula of Domestic Resource Cost (DRC) on social price condition is :

$$
D R C R=\frac{\text { Cost of Input Non Tradeable }}{\text { Social Revenue }- \text { Cost of Input Tradeable (Social) }}
$$




\section{Private Cost Ratio (PCR)}

Competitive advantage (Porter,1998) is an analytical tool used to measure the level of efficiency in financial values that shows the ability of a commodity system to pay for domestic resource costs even though it remains competitive. One method used is Private Cost Ratio (PCR). The formula of Domestic Resource Cost (PCR) on privat price condotion is:

$$
P C R=\frac{\text { Cost of input Non }- \text { tradeable }}{\text { Private Revenue }- \text { Cost of input tradeable (private) }}
$$

\section{Sensitivity Analysis}

Gittinger (1986) describes the sensitivity analysis which is an analytical tool used to look at the effects that have occurred as a result of changing circumstances. According to the researchers this analysis is very useful in the field of agriculture, given that this field can not be predicted with certainty the results to be obtained, it can be said that the agricultural field always faces the problem of uncertainty.

The relation with analysis of comparative and competitive advantage in cassava commodity by DRC and PCR method is to see the effect of change of important variables in cassava farming activities. Changes to variables that are considered important in the activities of cassava farming are changes to the price of output that explains the acceptable results that have been obtained as well as see the change in price increase of inputs tradeable on anorganic fertilizers.

\section{RESULTS AND DISCUSSION}

\section{Financial and Economic Analysis}

Financial and economic analysis aims to determine the total cost incurred, the total revenue and profits earned by farmers in the activities of cassava farming using private prices and social prices. Profits obtained by farmers in cassava farming in Simalungun Regency in Finasial and economic can be seen in Table 2.

Table 2. Analysis Farming Cassava (Rp/ha/MT)

\begin{tabular}{clcc}
\hline No & \multicolumn{1}{c}{ Description } & Financial & Economic \\
\hline 1 & Input : & & \\
& Input Tradeable & 904,221 & 947,497 \\
& Input Non Tradeable & $12,532,604$ & $12,532,604$ \\
2 & Revenue & $20,049,327$ & $65,267,565$ \\
3 & Profit & $6,612,502$ & $51,787,464$ \\
& R/C Ratio & 1.49 & 4.84 \\
\hline
\end{tabular}

Source : Primary Data, 2018 (processed)

Cassava farming in Simalungun Regency is profitable financially and economically. For receipt seen from the financial aspect obtained by $\mathrm{Rp}$ 20.049.327/Ha with the average production 39,9 ton $/ \mathrm{Ha}$ and the sale price is $\mathrm{Rp} .498 / \mathrm{kg}$, while for the total cost incurred during cassava cultivation in Simalungun Regency reached Rp 13.436.828/Ha includes fixed costs, namely depreciation of agricultural equipment and land rent and variable costs include the procurement of seeds, fertilizers, pesticides and labor costs. From the calculation of costs above the income obtained obtained $\mathrm{Rp}$ $6.626 .794 / \mathrm{Ha}$ with the R/C ratio of 1.49 . Values showing greater than 1 are considered to be a favorable economic activity that deserves to be developed.
For the activities of cassava farming in Simalungun Regency if viewed economically using the prevailing prices in the international market, is also said to be profitable. The acceptance of cassava farming is Rp. 65,267,565/hectar with the selling price is $\mathrm{Rp} 1,635 / \mathrm{kg}$. For the total cost

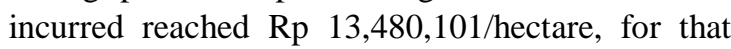
results obtained income is seen economically $\mathrm{Rp}$ $51,787,464 /$ hectare with the value of $\mathrm{R} / \mathrm{C}$ ratio of 4,84 where the value is greater than the number 1 means that cassava farming in Simalungun Regency should be developed even if used by the prevailing social prices in the international market. The social price includes the price of shrinkage of agricultural equipment and the price of inorganic fertilizers. For the selling price will also follow the price in the international market of $\mathrm{Rp} 1,635 / \mathrm{kg}$ 
compared with the actual price of $\mathrm{Rp} 498 / \mathrm{kg}$, the difference is so great for farmers.

\section{Analysis of Comparative Advantages of Cassava Farming in Simalungun Regency}

Comparative advantage is an analysis tool where to determine the competitiveness of a commodity that has been carried out. In this analysis the researcher will use DRC (Domestic Resource Cost) analysis which functions to determine the efficiency of the resources that have been used in cassava farming in Simalungun Regency. The results of the DRC analysis will determine whether the use of resources used is efficient, seen at table 2.

$$
D R C R=\frac{12,532,604}{65,267,565-947,497}=0.1948
$$

The value of DRR 0.1948 means that the comparative advantage in cassava farming is higher because its DRCR value is near zero. The value of DRCR is less than one defined as a business activity that has comparative advantage and is feasible to be developed domestically, and indicates a more profitable economic activity in the utilization of domestic resources if the production of such goods or services in the country rather than import them.

\section{Analysis of Competitive Advantage on Cassava Farming in Simalungun Regency}

Competitive advantage is an analytical tool used to measure the level of efficiency in financial values that shows the ability of a commodity system to pay for domestic resource costs even though it remains competitive. One method used is Private Cost Ratio (PCR). PCR is an analytical tool that shows the value between input costs at the actual price and the difference between actual revenue and tradeable input costs at the actual price, seen at table 2 .

$$
P C R=\frac{12,532,604}{20,049,327-904,221}=0.655
$$

Obtained a PCR value is 0.655 . The results explain that cassava farming in Simalungun Regency has a competitive advantage and has been able to finance non-tradeable inputs at the private price level (actual prices). Cassava farming that has been run in Simalungun Regency is said to be able to compete with cassava products in other regions and able to compete in domestic market and international market especially in facing free trade.

\section{Matrix Policy of Cassava Farming in Simalungun Regency}

The next step is Policy Anaysis Matrix, is an analysis model used to analyze comparative advantage (economic analysis) and competitive advantage (financial analysis) of a commodity that was first introduced by Monke and Pearson in 1989. PAM matrix consists of two identities, profitability identity and divergences identity.

The profit identity table PAM is the relationship between cross-column and matrix calculations. Profits are defined as income minus costs. All numbers under a column named profits are automatically identical to the difference between columns containing revenue and columns that contain costs (including tradeable input costs and domestic factors).

Identity deviation (divergences identity) is a cross-line relationship from a matrix. Divergence causes the private price of a commodity to differ from its social price. Divergence increases, either because of the influence of distortive policies, which causes private prices to differ from their social prices, or because market forces fail to produce efficiency prices. All numbers in the third row of the table PAM are defined as the effect of divergences and equal to the difference between the first row (private price) and the second line (social price).

The PAM matrix consists of three rows and four columns (Table 3). The first line estimates the private cost, which is the calculation of revenues and costs based on the prevailing price, which reflects the values that are influenced by government policy. The second line estimates economic superiority and competitiveness (comparative advantages), namely the calculation of revenues and costs based on the social price (shadow price) or economic value that actually occurs on the market without government policy. While the third row is the difference between the first and second lines that describe divergence. For more details, see Table 3 . 
Table 3. PAM of Cassava Farming

\begin{tabular}{ccccc}
\hline \multirow{2}{*}{ Indicator } & $\begin{array}{c}\text { Total Revenue } \\
(\mathrm{TR})\end{array}$ & Input Tradeable & $\begin{array}{c}\text { Cost } \\
\text { Input Non Tradeable }\end{array}$ & $\begin{array}{c}\text { Profit } \\
(\pi)\end{array}$ \\
\hline Privat Cost & $20,049,327$ & 474,813 & $12,947,720$ & $6,626,794$ \\
Social Cost & $47,351,476$ & 545,236 & $12,947,720$ & $33,858,520$ \\
Divergensi & $-27,302,149$ & $-70,423$ & 0 & $-27,231,726$ \\
& $(\mathrm{I})$ & $(\mathrm{J})$ & $(\mathrm{K})$ & $(\mathrm{L})$
\end{tabular}

Source : Primary Data, 2018 (processed)

The value in column I (output transfer) is the difference between the receipts at the condition of private prices and social prices, which indicates that the acceptance of social prices is higher than the private price. This shows that there is no policy on the protection of cassava output so the private price of cassava is lower than its social price.

Column J (Tradeable Input Transfer) where the results obtained are the difference between the costs incurred on inputs both the input tradeable and non-input on the condition of private prices and social prices. The value of column $\mathrm{J}$ shows a negative result of $\mathrm{Rp}$. $-70,423$. negative results have a positive impact on farmers, as the costs incurred when measured at prices using social prices outweigh the actual price that farmers have paid. So there is special attention to the procurement of tradeable inputs, such as low fertilizer prices due to government subsidies.

For column K (Factor Transfer) where the result of the difference between the non-input on the condition of private price and social price equal to zero. This means that there is no market failure or policy distortion that can lead to differences between the two costs. The non-farm input costs incurred by the farmers at the actual prices are the same as those that should be paid by farmers at prices in the international market.

The last is the L (Net Transfer) column where the difference between the profits at the private and social prices is minus Rp.27.231.726. The results mean that farmers earn less profit than the profits that should be accepted by farmers. And these results indicate market failure and policy distortion.

\section{Sensitivity Analysis of Comparative Advantage on Cassava Farming in Simalungun}

It is assumed that the increase in fertilizer prices from private prices increases by about $10 \%$ and $20 \%$, if there is an increase in fertilizer prices, it will affect the total production costs incurred and impact on farmers' income. Sensitivity analysis will look at the sensitivity of the comparative advantage of cassava farming in Simalungun District to the increase in the price of input for inorganic fertilizer production.

Table 4. Analysis of Compartive Advantages while increase of input tradeable price (fertiliser).

\begin{tabular}{clrrr}
\hline No & \multicolumn{1}{c}{ Information } & Normal Price & \multicolumn{1}{c}{ Up 10\% } & \multicolumn{1}{c}{ Up 20\% } \\
\hline 1 & Input Non Tradeable & $12,532,604$ & $12,532,604$ & $12,532,604$ \\
2 & Input Tradeable & 947,497 & $1,012,516$ & $1,055,806$ \\
3 & Output of Production & $65,267,565$ & $65,267,565$ & $65,267,565$ \\
& (Fresh root of Cassava) & & & 0.1952 \\
\hline
\end{tabular}

Source : Primary Data, 2018 (processed)

Changes in the price of the tradeable inputs resulted in an increase in the cost of inputs of tradeable fertilizer from $\mathrm{Rp} 947.497$ which increased $10 \%$ to $\mathrm{Rp} 1.012 .516$, rising again by $20 \% \mathrm{Rp} 1.055 .806$. The price changes will affect farmers 'income where farmers' income is derived from total receipts less the product costs including tradeable inputs and non-tradeable inputs. For DRCR value is still said to be safe, changes in input prices increased $10 \%$ and $20 \%$ yielded DRCR values of 0.1950 and 0.1952 respectively. The result shows the value of DRCR $<1$ which means that the activities of cassava farming on the farmer's road in Simalungun Regency is feasible to be cultivated and better produced domestically than import it. 


\section{Sensitivity Analysis of Competitive Advantage on Cassava Farming in Simalungun}

For the second assumption, the price of cassava is reduced by $10 \%$ and $20 \%$ at the private price level. According to the results of interviews with farmers, the price of cassava in Simalungun Regency from year to year experienced a very significant decline. For the second assumption is a decrease of cassava output price by $10 \%$ and $20 \%$ at private prices. The actual (actual) price of Rp.498 / $\mathrm{kg}$ decreased $10 \%$ to Rp.448 / kg decreased another $20 \%$ to Rp.398 / $\mathrm{kg}$. The results of PCR indicate a safe condition where the results are less than 1 . If excessive number 1 can be stated that the cassava farming in Simalungun Regency is not feasible to be cultivated either comparatively or competitively.

Table 5. Analysis of Competitive Advantages while decrease of output price

\begin{tabular}{clrrr}
\hline No & \multicolumn{1}{c}{ Information } & Normal Price & Down 10\% & \multicolumn{1}{c}{ Down 20\% } \\
\hline 1 & Input Non Tradeable & $12,532,604$ & $12,532,604$ & $12,532,604$ \\
2 & Input Tradeable & 947,497 & 947,497 & 947,497 \\
3 & Price of Output & 498 & 448,2 & 398 \\
4 & Output of Production & $20,049,327$ & $17,891,660$ & $15,887,762$ \\
& (Fresh root of Cassava) & & & 0.836 \\
5 & Private Cost Ratio (PCR) & 0.655 & 0.738 & 0.80 \\
\hline
\end{tabular}

Source : Primary Data, 2018 (processed)

As for the value of PCR less than one suggests that cassava farming in Simalungun is very efficient against the use of domestic input and able to compete in international trade.

From the sensitivity analysis here is also known how the lowest minimum limit of cassava prices is indicated by the PCR value that is close to one. The results of the PCR value indicate that the lowest price of farmers is at least Rp. $388 / \mathrm{kg}$, where the PCR value of 0.836 is close to one.

\section{CONCLUSION}

1. Cassava farming in Simalungun Regency is said to be financially profitable, seen from the R/C ratio of 1.49. While economically it is said to be advantageous from the $\mathrm{R} / \mathrm{C}$ ratio of 4.84

2. Cassava farming in Simalungun District has a comparative advantage seen from the results of DRCR (Domestic Resource Cost) of 0.1948. While the competitive advantage of cassava farming is seen from the PCR (Private Cost Ratio) value of 0.655 .

3. Increasing the price of tradeable inputs on comparative advantage yields a value of 0.1950 when tradeable input prices rise by $10 \%$ and 0.1952 when tradeable input prices rise by $20 \%$. Whereas for the reduction of the output price of $10 \%$ and $20 \%$ respectively, the PCR value on the competitive advantage is 0.738 and 0.836 .

\section{REFERENCES}

Central Data Statistics Republic Indonesia. 2017. Development of Cassava Production in Indonesia. www.bps.go.id. Retrieved October 5,2017

Department of Industry and Trade Republic Indonesia. 2017. Imports of Cassava in Indonesia. www.kemendag.go.id. Retrieved January 1, 2018

Dermawan, Wibisono. 2005. Research \& Data Analysis Methods. Jakarta: Salemba Medika.

Dollar, David. 1993. Technological Differences as a Source of Competitive Advantage. American Economic Review 83 (2) 445-449.

Gittinger, J.P. 1986. Economic Analysis of Agricultural Projects. Translation. Second Edition. Jakarta: UI-Press and John Hopkins.

Krugman, Paul R., Obstfeld, Maurice, and Melitz, Marc J. 2012. International Economics Theory \& Policy, ninth edition. Pearson Education. Boston.

Monke, E.A dan S.R Pearson.1989. The Policy Analysis Matrix for Agriculture Development. London : Cornell University Press.

Porter, Michael E. 1998. "Competitive Strategy" Techniques for Analysing Industries and Competitors. New York: The Free Press.

Soekartawi. 1993. Basic Principles of Agricultural Economics, Theory and The Application. Jakarta: Rajawali. 
Abdullah, Petter 2002. Regional Competitiveness of Concepts and Measurement in Indonesia. Yogyakarta: BPFE

Dewi, Heptari. 2013. Comparative Advantages and Impact of Policy on Reducing Subsidies on Potato Development in Batu City. Thesis. Malang: University of Brawijaya.

Linanda, Anggraini. 2015. Analysis Competitive and Comparative Advantages of Robusta Coffee Farming in Pugung District, Tanggamus District. Essay. Bandar Lampung. University of Lampung.

Pearson, Scott et al. 2005. Application of Policy Analysis Matrix on Indonesian Agriculture. Jakarta: Yayasan Obor Indonesia.
Pudjosumarto, Mulyadi. 1984. Introduction to Project Evaluation. Malang: University of Brawijaya.

Hady, H. 2004. International Trade Theory and Policy. Jakarta: Ghalia Indonesia.

Irawan and Suparmoko. 1992. Development Economics, Yogyakarta: BPFE Yogyakarta.

Krugman, Paul R., Obstfeld, Maurice, and Melitz, Marc J. 2012. International Economics Theory \& Policy, ninth edition. Pearson Education. Boston.

Lindert, P.H. and Ch. P. Kindleberger, 1993. International Economy Eighth Edition. Jakarta: Erlangga

Ricardo, David. 1817. On The Principles of Political Economy and Taxation, London: Jhon Murray 